\title{
DOSSIÊ COMEMORATIVO
}

\section{AAD-69: UMA OBRA FUNDADORA E A CONSTRUÇÃO DE UM NOVO OBJETO}

Há um acontecimento discursivo maior no domínio da análise de discurso que festejamos neste ano: os 50 anos da publicação, pela editora Dunod, de Paris, do livro fundador de Michel Pêcheux Analyse Automatique $d u$ Discours. Este acontecimento tem sido festejado por nós de várias maneiras. Antes de tudo, em nosso cotidiano de pesquisadores da linguagem, por darmos um lugar importante à leitura deste, e de outros textos do autor, e reconhecer, nesta obra, um forte instrumento na formação de analistas de discurso.

De forma mais direta, decidimos, na revista Línguas $e$ Instrumentos Linguísticos, fazer um dossiê, em um número, que se torna assim especial, da revista, com artigos de conhecidos analistas de discurso no Brasil, para compor este dossiê.

O mérito do autor já é conhecido e reconhecido não só, mas, sobejamente, no Brasil, onde tem produzido uma reflexão sobre a linguagem que a ele se filia em suas múltiplas consequências. Retomadas, reelaborações, deslocamentos se dão, tanto nos textos do autor, assim como em textos de nossos pesquisadores em análise de discurso. Vale mencionar que a prática da análise de discurso, assim concebida, passou a se chamar materialista, para se distinguir das variedades epistemo-pragmáticas e funcionalistas, que também têm seu desenvolvimento não só no Brasil como em outros lugares.

Mais do que falar sobre este acontecimento discursivo extensamente, o melhor é apresentar os artigos que aqui se conjugam para falar dele.

No artigo "A Análise de Discurso é Possível?", na esteira da história das ideias discursivas, faço, pois, neste texto-homenagem a Michel Pêcheux, uma exposição do que considero marcos importantes de sua reflexão e de constituição da ciência que é fundada em Análise Automática do Discurso. Destaco, assim, os muitos movimentos de

\section{(c) BY-NC-SA}

Líng. e Instrum. Linguíst., Campinas, SP, n. 44, p. 135-137, jul./dez. 2019 
busca, compreensão, explicitação, retomadas e deslocamentos, produzidos pelo autor.

Freda Indursky em "AAD-69: O marco histórico de um discurso fundador" acompanha o percurso traçado por Michel Pêcheux na obra "Análise Automática do Discurso", observando o modo como o autor produziu esta obra fundadora. A autora dá ênfase ao trajeto teórico empreendido pelo autor no estabelecimento de um novo objeto de análise, o discurso, no domínio dos estudos da linguagem.

Guilherme Adorno, no artigo "Algoritmizar a língua? Automatização, informatização, materialismo discursivo", procura ler uma história da "Análise Automática do Discurso", a fim de compreender o funcionamento das dificuldades e dos obstáculos decorrentes dos procedimentos automáticos na elaboração da teoria discursiva.

Cristiane Dias põe em questão a leitura e interroga a automatização sobre o que ela, enquanto processo discursivo, pode fazer compreender a propósito da constituição dos sentidos, sobre o discurso e sobre a maquinaria dos sentidos, no artigo "O sentido da automatização na análise de discurso: sobre a maquinaria dos sentidos".

Maraisa Lopes apresenta o Sinalário de Análise de Discurso em seu processo de produção que visa abrir possiblidades de leituras da/sobre a análise de discurso na comunidade surda. Em "Da AAD-69 ao sinalário: leituras da/sobre a análise de discurso", a autora discorre sobre esse processo, mostrando a formulação dos sinais de Ideologia, Posição-sujeito e Michel Pêcheux.

Mariza Vieira da Silva em "Análise de discurso: um percurso de leitura e de gestos de interpretação" examina como os sentidos de linguagem são determinados pelos sentidos de comunicação em livros didáticos, chamando a atenção para o funcionamento da administração das possibilidades de interpretação de textos.

Em "As formas discursivas e a ameaça comunista", Bethania Mariani, trabalha, sobretudo, com o conceito de formas discursivas remissivas, apresentado por Pêcheux em 1969, para analisar os processos de produção de sentidos em torno das palavras comunismo, comunista e esquerda, na discursividade política brasileira.

Suzy Lagazzi se dedica em "Entre o amarelo e o azul: a história de um percurso" a traçar uma análise, tendo como ponto de ancoragem a 


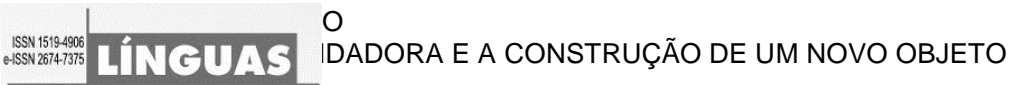

e InSTRUMENTOS

"composição material", trabalhada na relação entre a capa e os contos do livro "No seu pescoço", de Chimamanda Ngozi Adichie. A autora dá a ver a potência do dispositivo de leitura proposto por Pêcheux à medida que procede às análises do funcionamento da resistência simbólica.

Sérgio Freire em "Da Análise Automática do Discurso ao discurso do sujeito do desejo: reflexões psicanalíticas sobre a teoria do discurso de Michel Pêcheux" propõe um percurso de leitura em torno da ligação do Discurso com a Psicanálise.

Por fim, Helson Flávio da Silva Sobrinho encerra este dossiê com a resenha de "Análise Automática do Discurso (1969)" intitulada "AAD-69: uma referência incontornável". Em seu texto, o autor destaca que a apreciação desta obra fundadora demanda uma retomada de memórias históricas de práticas científicas e políticas e, ao mesmo tempo e sobretudo, requer uma reflexão sobre a atualidade, tendo como horizonte a possibilidade de "arriscar dar novos passos em direção ao futuro, em estreita relação crítica com nosso tempo histórico".

Eni Puccinelli Orlandi 